\title{
The Features of Social Partnership as a Mechanism for the Integration of Education and Production
}

\author{
Albina R. Shaidullina ${ }^{1}$, Aleksei V. Morov ${ }^{2}$, Natalya S. Morova ${ }^{2}$, Tatyana N. Petrova ${ }^{3}$, Olga V. Kirillova ${ }^{4}$, Tatyana \\ V. Kirillova ${ }^{5}$ \& Irina M. Riazantzeva ${ }^{3}$ \\ ${ }^{1}$ Almetyevsk State Oil Institute, Almetyevsk, Russia \\ ${ }^{2}$ Mari State University, Yoshkar-Ola, Russia \\ ${ }^{3}$ Chuvash State Pedagogical University named after I. Y. Yakovlev, Cheboksary, Russia \\ ${ }^{4}$ Chuvash State University named after I. N. Ulyanov, Cheboksary, Russia \\ ${ }^{5}$ Academy of Law and Administration of the Federal Penitentiary Service, Ryazan, Russia
}

Correspondence: Albina R. Shaidullina, Foreign Languages' Department, Almetyevsk State Oil Institute, Almetyevsk, 423450, Russia. E-mail: albina-plus@mail.ru

Received: January 17, 2015 Accepted: January 29, 2015 Online Published: February 26, 2015

doi:10.5539/res.v7n3p292 URL: http://dx.doi.org/10.5539/res.v7n3p292

\begin{abstract}
In present time the development of partnership between education and employment is becoming increasingly important. The interaction between professional education institutions and employers appears as an integral part of social partnership. In this context, this article aims to identify the features of social partnership as a mechanism for the education and production integration. The paper presents the objectives, tasks, principles, forms, benefits (for the students of the professional education institutions and the occupational sector), the criteria and performance indicators of social partnership, the key directions of its progression. The article findings can be valuable for the heads of the secondary and higher vocational education institutions, representatives of the manufacturing sector as well as for the researchers concerned with the issues of integration of education and production.
\end{abstract}

Keywords: social partnership, integration, professional education, production

\section{Introduction}

Social partnership in the framework of the relationship formation between the system of professional education, state and local authorities, agents of the employment market, public organizations concedes coordination of interests of the stakeholders. Unfortunately, it should be recognized that the existing partnership between educational institutions and enterprises is insufficient (Smirnov, Polyakov, \& Tkachenko, 2004). The graduates from many educational institutions get a qualification and go virtually "nowhere". Moreover, the skills they possess can hardly be applied in modern conditions as they have been trained to use the out-of-date equipment (obsolete institution equipment). As a result, a young professional cannot be effectively involved in the work process to meet the employer's requirements. There is an urgent need for retraining of the young specialists, training him for practical skills within the chosen specialty (Shaidullina et al., 2015). Consequently, the process of vocational education should be continuous and adjustable according to the needs of employers.

In circumstances of modern economy it is necessary to find new approaches to the construction of the social partnership system: vocational guidance of the students, their adaptation to the new socio-economic conditions (Muratov, 2009; Sibgatova et al., 2015). The State plays the leading role in the vocational education management as it creates conditions for transition to a more effective mechanism of social partnership taking into account the interests of the society, the economy, education and personality although the tendency of rearranging the leading role of the state in favor of the employers and their associations is gradually upwarding.

\section{Literature Review}

The term "social partnership" is a new one for Russian educational space and often is perceived ambiguously. According to G. V. Mukhametzyanova, the meaning of this concept is "to establish constructive interaction between the three really effective forces in Russia socially: the government institutions, the commercial (private) 
educational institutions and noncommercial organizations" (Mukhametzyanova, 2005). This definition, in our opinion, is different as the author emphasizes the main feature of social partnership - "building constructive interaction...". Firstly, it is referred to the constructive nature of the interaction that supposes serving the interests of all partnership agents; and secondly, it pays attention to the word "building...", which emphasizes the fact that the subjects of social partnership should perform particular activities, take steps to ensure the partnership would become constructive. In other words, social partnership is not just a number of some organizational structures but a dynamic and constructive interaction process.

At the same time in the analyzed definition the number of agents of social partnership is limited. It does not include, for example, employers in the private sector; it is difficult to find a place for such partners as parents, social structures. The author truthfully points out that every of the selected entities mentioned in the definition of social partnership is aware of its responsibility to participate in solving the problems of education in a different way, they have different capabilities and resources to help each other.

Consideration of social partnership in vocational education as a crucial interaction between the educational institutions and economic and social institutions is not a mere coincidence as in the market environment the economic interests become the most important for all members of the partnership. Secondly, G. V. Mukhametzyanova states the importance of living connection between the subjects of social partnership (Mukhametzyanova, 2005). The live link means that the interaction of the partnership agents should be performed at the level that assumes the direct immediate communication, information exchange, joint projects performed by the particular people - the representatives of the social partners. Social partnership should not be limited within just fixing noncommittal agreements. It assumes following the contractual commitments by all parties of the partnership - the schools, businesses, community organizations, educational authorities, government agencies, research institutions of the Russian Academy of Education and others.

The analyzed paper discusses the priority areas and forms of social partnership. The priority areas include participation in developing national standards for the specialized enterprise professions; enterprise participation in the qualification testing and personnel selection for the enterprise; participation in the development of educational curriculum for the allied professions; developing the requirements to the levels of the students' over-professional qualifications (computer skills, basic management knowledge, foreign languages, etc.); specifying the requirements to personal qualities of the graduate.

Describing social partnership we can take into account a large number of relationships aimed at improving the quality of training, and each institution has its own system of such work.

I. P. Smirnov and E. V. Tkachenko discussing the problem of social partnership emphasized the complications impeding its effectiveness. At the same time they were focusing on the two groups of reasons: objective and subjective. The subjective reasons involve employers' disunity; rigid judgment of many leaders in the industry and educational institutions; lack of proper contact between the education authorities and employment services. The objective reasons that interfere with the effective social partnership include the absence of the legal basis for building the partnership; the absence of the tax system that upgrades the level of the company's professionalism (Smirnov \& Tkachenko, 2004).

G. I. Ibragimov in his work raises the problem of social partnership as one of the organizational mechanisms of the students' apprenticeship. Under the social partnership in vocational education he understands a special type of interaction between educational institutions and all participants of the labor market as well as its institutions, territorial administration aimed at maximizing the coordination and implementation of the interests of all agents in this process (Ibragimov, 2005). He identifies the following ways of cooperation of the institution with the agents of social partnership: specifying the list of educational services that are in demand in the labor market; setting the quality requirements for the specialists' qualifications and participation in the Final Certifying Examination; setting the requirements for quality of the curriculum papers; improving the organization of the educational process (human resources, exam, practical training); developing material and technical basis of the educational institutions; assessment of educational institutions performance, participation in licensing, certification and accreditation, vocational guidance; employment of the graduates.

\section{Results and Discussions}

\subsection{The Attributes of Social Partnership}

The main features of the social partnership in vocational education include the existence of two or more entities (institutions) of the labor market; a special type of interaction between the educational institutions (institutions) and the labor market agents; maximizing the coordination of the interests of all parties, the implementation of the 
interests of all participants of interaction; the membership of the interaction are: the participants of the labor market; the labor market institutions; public authorities; municipal authorities; non-governmental organizations.

\subsection{The Objectives and Tasks of Social Partnership for the State and the System of Vocational Education}

The main purpose of social partnership is to coordinate and promote the interests of all the interacting parties. In this regard, it is important to clearly represent the interests of the parties. Therefore, the state regards social partnership as the most effective form of the development and implementation of the state policy in the field of vocational education. For the system of vocational training social partnership is a natural form of existence. An educational institution closely cooperating with the employers receives new additional advantages:

- Firstly, there is a constant access to information about the labor market situation, thus it allows to clarify the structure of the professions and specialties and adjust the curriculum of the training courses;

- Secondly, there is an actual opportunity to take into account the employers' requirements for graduation at the expense of the joint development of the vocational education standards, the curricula and the programs;

- Thirdly, there appear viable opportunities for the students' apprenticeship using the equipment operating in modern production environment;

- Fourth, it becomes possible to organize continuous teachers training at the enterprises to learn about the latest types of equipment and production processes;

- Fifth, it increases opportunities for the targeted training of the specialists for a particular company which in turn facilitates the graduate employability;

- Sixth, there appears a mechanism for an objective assessment of the quality of training of specialists by the independent expert commissions with the tests developed in conjunction with the employers;

- Seventh, there are conditions for joint projects to increase non-budgetary funds of the educational institutions including refresher courses for the employees, the use of training facilities to execute the enterprise orders and others.

\subsection{The Principles of Social Partnership}

The principles on which the social partnership is built nowadays include integration of the labor world and education within a diverse range of issues related to training; multi-level social partnership structure in vocational education (federal, regional and municipal level); equality of the participants of social interaction; legal support and voluntary character of the partnership.

\subsection{The Forms of Social Partnership}

One of the most effective forms of partnership is a targeted training for enterprises, organizations, businesses and even individual systems (law enforcement agencies, banking institutions, social services, etc.). The targeted or task training can be implemented in various schemes of the educational process and can be carried out through: the adaptation of the elective curriculum and disciplines programs in respect to the particular enterprise; the course and qualification projects basing on the specificity of the enterprise; all types of traineeship at the enterprise; attracting outstanding scientists and leading specialists of the enterprise to teaching special disciplines for the students, classes and laboratory works at the enterprise if necessary; retraining the teachers at the enterprise.

Cooperation with social partners is also aimed at improving the vocational training curriculum, it is realized through such forms as: practical training of the students at real workplace; individual tutorials with the employers' representatives; employers' participation in students qualification; teachers apprenticeship at real workplace; employees' booster training (employers' representatives) in the educational institution; employment of the graduates; employers' participation in the Board of Trustees of the educational institution (Mukhametzyanova \& Pugacheva, 2007).

Another form of social partnership is the involvement of the employers in the independent quality assessment of the graduates' qualification which is aimed at solving one of the most important tasks - to find out if they meet the requirements of the labor market. Therefore, the representatives of businesses and organizations participating in the final certification of the graduates pay attention not only to the students' knowledge, but also their readiness to solve the socio-professional and professional tasks. However, there are situations when the involvement of the employers in final certification ends with the end of the qualification exams (Shaidullina et al., 2015; Oleinikova, 2000). Moreover, there have been the cases of formality in the assessment of the graduate qualification by the employers. One of the reasons for this is that the employers participating in the evaluation do 
not make any contribution to training, do not invest any funds in this process. Anyway some graduates receive a job offer.

This collision can be solved with the targeted training as a form of social partnership. The essence of this training form lies in the employer's compensation for the cost of the future professionals training under the condition of their further working for the enterprise. In this case the employer turns out to be really interested in his investments in training funds to give the maximum effect. Therefore, in such circumstances the educational institution finds a reliable partner that is involved not only in backing the education, but also provides environment for apprenticeship and helps to solve the problem of graduates employment.

\subsection{The Benefits of Social Partnership}

\subsubsection{For the Student}

Social partnership allows the student to: in advance get acquainted with the leading enterprises, working conditions, specifics of the production organization, etc.; take part in various types of educational practices at the core enterprises, operating divisions; take part in the targeted contract training arranged by the university at the corporate customers of the human resources; to be employed for the plant while studying at the university (temporary employment) with the support of university graduate departments and relevant business units and others.

\subsubsection{For the Institutions of Professional Education}

Social partnership allows the institutions of vocational education: to provide guaranteed employment for its graduates thus improving significantly its good standing in the professional and social environment; use the production, material and technical basis of the partner companies for different types of practices prescribed by the curricula as well as for seminars, laboratory classes; attract leading experts from the partner companies to teach courses, tutor course and diploma projects performed by the students; ensure the implementation of the latest scientific and technical achievements into the educational process; receive additional funding from partner companies for the target contract training and development of the own material and technical basis, etc.

\subsubsection{For Businesses}

Social partnership allows manufacturing companies, design offices, research centers, institutions facilitate their activities in searching, attracting and employing young specialists on a scheduled basis reducing the dependence on changes in the labor market; ensure the formation of a network of stable and versatile multi-level relationships with university departments and potential candidates for employment; make a selection of the candidates for employment among the graduates and undergraduates with the assistance of the universities and specialized state and / or municipal youth centers; develop and implement the targeted programs with the university; significantly reduce the duration of the professional and socio-psychological adaptation of young professionals to the conditions of the workplace; make the enterprise known with such activities, improve its image in the eyes of young people through media, including those financed by the authorities and / or their institutions.

\subsection{The Criteria and Indicators of the Social Partnership Effectiveness}

The main criterion of the social partnership effectiveness is the demand for the graduates in the labor market, which is expressed by the number of employed people, the work quality offered by employers, lasting attachment to the workplace.

For the educational institution the criterion for the effective demand in the education market is no less important. In fact, these two criteria are closely related the demand for graduates in the labor market and the demand for the institution in the education market, which is the leading criterion of efficiency within a market economy. We cannot but mention other features of the vocational education-the common cultural development of the individual (Ignatiev, 2005; Ivanov et al., 2015).

We should also mention another criterion that is related not so much to the graduates (although it applies to them) but to the entire institution. We are talking about the demand for the institution in the labor market, its ability to expand its market sector. This raises the question of indicators by which one can assess this criterion. The major indicator is the competition for admission to the university. But the ability to expand the market sector can be judged by the number of new specialties and specializations offered by the university, the new geography regions, new courses offered to various audiences as part of additional educational service; by various financing channels and so on. We also think that the ability to expand the market sector can be judged by a number of new branches and representative offices of the institution. The establishment of the branches is the most effective way to 
expand the sector in the educational market, as the educational service appears closer to the consumer - future students. This way becomes very important for rural areas that are far from the cities where most of the technical schools, colleges, institutes and universities are located.

\subsection{The Directions for Social Partnership Development}

The development of social partnership requires further improvement of the legislation on social partnership that urges:

- To develop a model of partnership and prepare appropriate guidelines for secondary and higher education;

- To facilitate a complex marketing research of the labor market and educational services;

- To encourage investments aimed at developing vocational training through the mechanism of tax abatement;

- To continue creating conditions to motivate the social partners to participate in vocational education;

- To develop effective mechanisms of interaction of the system of vocational education and the labor market in order to plan soundly the volume, structure, content and the workers' quality assessment;

- To develop the legal framework of co-founding of the enterprises and the educational institutions of basic and secondary vocational education.

\section{Conclusions}

Social partnership in vocational education implies: social need to be included in the fulfillment of the educational values; readiness of the vocational training institutions for such cooperation; the initiativity of the institution of vocational education; the creativeness of other subjects related to training (employers, state and local authorities, heads of the educational institutions, parents, students, community organizations, and others). Following these conditions will help to ensure that social partnership will help to direct resources to the development of vocational education, social self-organization and self-management. It will attract the society resources to support education and promote the development of vocational education in the traditions and practices of civil liability, philanthropy, volunteerism. Today social partnership is able to create local real structures of the Russian civil society and ensure their sustainable development.

\section{References}

Ibragimov, G. I. (2005). The problem of social partnership in vocational school pedagogy (p. 248). Scientific basis for the preparation of a competent expert in high school.

Ignatiev, N. S. (2005). Social partnership as a condition for improving the quality of training in college (p. 230) (PhD Thesis). Kazan.

Ivanov, V. G., Shaidullina, A. R., Drovnikov, A. S., Yakovlev, S. A., \& Masalimova, A. R. (2015). Regional Experience of Students' Innovative and Entrepreneurial Competence Forming. Asian Social Science, 11(1), $35-40$.

Mukhametzyanova, G. V. (2005). Professional education: Issues of quality and scientific and methodological support (p. 319). Kazan.

Mukhametzyanova, G. V., \& Pugacheva, N. B. (2007). The cluster approach to the management of vocational education (p. 144). Kazan.

Muratov, R. F. (2009). Problems and integration processes in the education system. Kazan pedagogical journal, $1,3-23$.

Oleinikova, O. N. (2000). Social partnership in the field of vocational education in the Netherlands. Vocational education, 6, 36-39.

Shaidullina, A. R., Fassakhova, G. R., Valeyeva, G. K., Khasanova, G. B., Komelina, V. A., \& Ivanova, T. L. (2015). A Comparative Research on Levels of Students' Formation Skills of Their Career Advancement Portfolio in Secondary and Higher Education Systems. Asian Social Science, 11(1), 375-379.

Shaidullina, A. R., Krylov, D. A., Sadovaya, V. V., Yunusova, G. R., Glebov, S. O., Masalimova, A. R., \& Korshunova, I. V. (2015). Model of Vocational School, High School and Manufacture Integration in the Regional System of Professional Education. Review of European Studies, 7(1), 63-67.

Sibgatova, K. I., Mirzagalyamova, Z. N., Pupysheva, E. L., Mirzanagimova, F. I., Shkinderova, I. N., Nuriyeva, E. N., Masalimova, A. R., \& Schepkina, N. K. (2015). The Educational Institution Teachers and 
Professional Community Representatives' Readiness Formation for the Joint Pupils' Career Guidance Implementation. Review of European Studies, 7(1), 74-79.

Smirnov, I. P., Polyakov, V. A., \& Tkachenko, E. V. (2004). New principles of primary vocational education (p. 32). Moscow.

Smirnov, I. P., \& Tkachenko, E. V. (2004). Social Partnership: What will happen with employers? (p. 32). Moscow.

\section{Copyrights}

Copyright for this article is retained by the author(s), with first publication rights granted to the journal. This is an open-access article distributed under the terms and conditions of the Creative Commons Attribution license (http://creativecommons.org/licenses/by/3.0/). 